\title{
The Rudnik Mts. volcano-intrusive complex (central Serbia): An example of how magmatism controls metallogeny
}

\author{
Vladica Cvetković1, Kristina Šarić1, Zoltán Pécskay² and Axel Gerdes ${ }^{3}$
}

${ }^{1}$ University of Belgrade - Faculty of Mining and Geology, Đušina 7, 11000 Belgrade, Serbia

(vladica.cvetkovic@rgf.bg.ac.rs; kristina.saric@rgf.bg.ac.rs)

${ }^{2}$ Institute of Nuclear Research of the Hungarian Academy of Sciences, Bem ter 18/c, 41001 Debrecen, Hungary

(zoltan.pecskay@gmail.com)

${ }^{3}$ Johann Wolfgang Goethe-Universität, Institut für Mineralogie, Seckenberganlage 28, 60054 Frankfurt am Main, Germany (gerdes@em.uni-frankfurt.de)

89-99 8 Figs.

doi: $10.4154 /$ gc. 2016.08

chesske

Article history:

Received October 02, 2015

Revised and accepted January 09, 2016

Avaliable online February 29, 2016

Keywords: Quartzlatite, Dacite, Magma mixing, Serbo-Macedonian metallogenic province

\begin{abstract}
This study reports and discusses new radiometric ages, petrographic and volcanological observations and whole rock geochemical data of the rocks of the Rudnik Mts. volcanointrusive complex. The complex belongs to the Serbo-Macedonian metallogenic belt and hosts a Pb-Zn-Ag deposit. Two distinct igneous events are distinguished. The first occurred, $>30 \mathrm{Ma}$ and was mainly characterized by extrusive and shallow intrusive dacites and andesites and was unrelated to mineralization. The second igneous event occurred $<23 \mathrm{Ma}$ and was highly heterogeneous in terms of its volcanic products and petrographic varieties, but with a strong predominance of quartzlatites. The dacite-andesites (first event) and the quartzlatites (second event) are geochemically similar and both display a calc-alkaline affinity and highly incompatible element enriched patterns on spider diagrams. However, the younger quartzlatites are richer in $\mathrm{K}_{2} \mathrm{O}, \mathrm{Rb}$ and $\mathrm{Ba}$ and poorer in $\mathrm{Sr}$. Along with other petrochemical characteristics; this is taken as evidence that mixing between ultrapotassic lamprophyre/lamproite magma and an acid calc-alkaline (dacite-like) magma were essential petrogenetic processes of the second event. The proposed simplified volcanological model suggests that mixing was responsible for triggering strongly explosive volcanic activity and for providing the conditions for active hydrothermal and mineralization processes. The observed link between a specific magmatic phase and ore deposit formation can be a general phenomenon in the Balkans, and must be addressed by further and more advanced studies.
\end{abstract}

\section{INTRODUCTION}

The Balkan sector of the Alpine-Himalayan orogenic belt is probably one of the best regions to study the relationship between magmatism and the formation of ore deposits. Two roughly subparallel magmatic and metallogenic belts stretch through this region. The eastern one is referred to as the BanatiteTimok-Srednjegorje magmatic and metallogenic belt; it is Late Cretaceous in age, and is associated with andesite to basaltic andesite, presumably subduction-related volcanic rocks, and is characterized by the $\mathrm{Cu}-\mathrm{Au} \pm \mathrm{Pb}-\mathrm{Zn}$ metallogeny of huge porphyry systems and high sulphidation epithermal gold deposits (JANKOVIĆ, 1997; VON QUADT et al., 2001, 2005; CIOBA$\mathrm{NU}$ et al., 2002, etc). The western belt stretches along the main axis of the Balkan Peninsula and is named the Serbo-Macedonian metallogenic (and magmatic) province (JANKOVIĆ, 1966/67, 1984). It is Cenozoic in age and is associated with predominantly $\mathrm{Pb}-\mathrm{Zn}-\mathrm{Ag} \pm \mathrm{Sb} \pm \mathrm{W}$ metallogeny.

The Cenozoic Serbo-Macedonian magmatic and metallogenic province is spatially and temporarily associated with magmatic rocks that have a wide compositional spectrum, from basalts to rhyolites and from tholeiitic to alkaline series (e.g. CVETKOVIĆ et al., 2004; PRELEVIĆ et al., 2005; MLADENOVIĆ et al., 2015). This compositional heterogeneity was the reason why at many places in this province, the interplay between magmatic and mineralization processes has only been vaguely established. A plethora of petrographic types and highly variable volcanogenic facies have prevented the researchers from reconstructing the rock petrogenesis in sufficient detail, which was the main prerequisite for better understanding of the link between magmatism and mineralization.

Over several decades recently, knowledge about the age, origin and evolution of Cenozoic magmatism in the central Balkans has seriously improved (CVETKOVIĆ et al., 2000a, b, 2001, 2004, 2007, 2013; JOVANOVIĆ et al., 2001; PRELEVIĆ et al., 2000, 2001a, b, 2004, 2005, 2007; KORONEOS et al., 2011; SCHEFER et al., 2011; BOROJEVIĆ ŠOŠTARIĆ et al., 2012; MLADENOVIĆ et al., 2015, among others). These studies provided a solid basis for refining the existing tectonomagmatic models and for making important steps forward in recognizing those magmatic processes that were essential for the formation of ore deposits. Although this information has already provoked new studies which suggest that some events of Cenozoic magmatism were more important for mineralization than others (e.g. BOROJEVIĆ ŠOŠTARIĆ et al., 2012, 2013; CVETKOVIĆ et al., 2014; MLADENOVIĆ et al., 2015), there are still many places where the true links between igneous pro- 

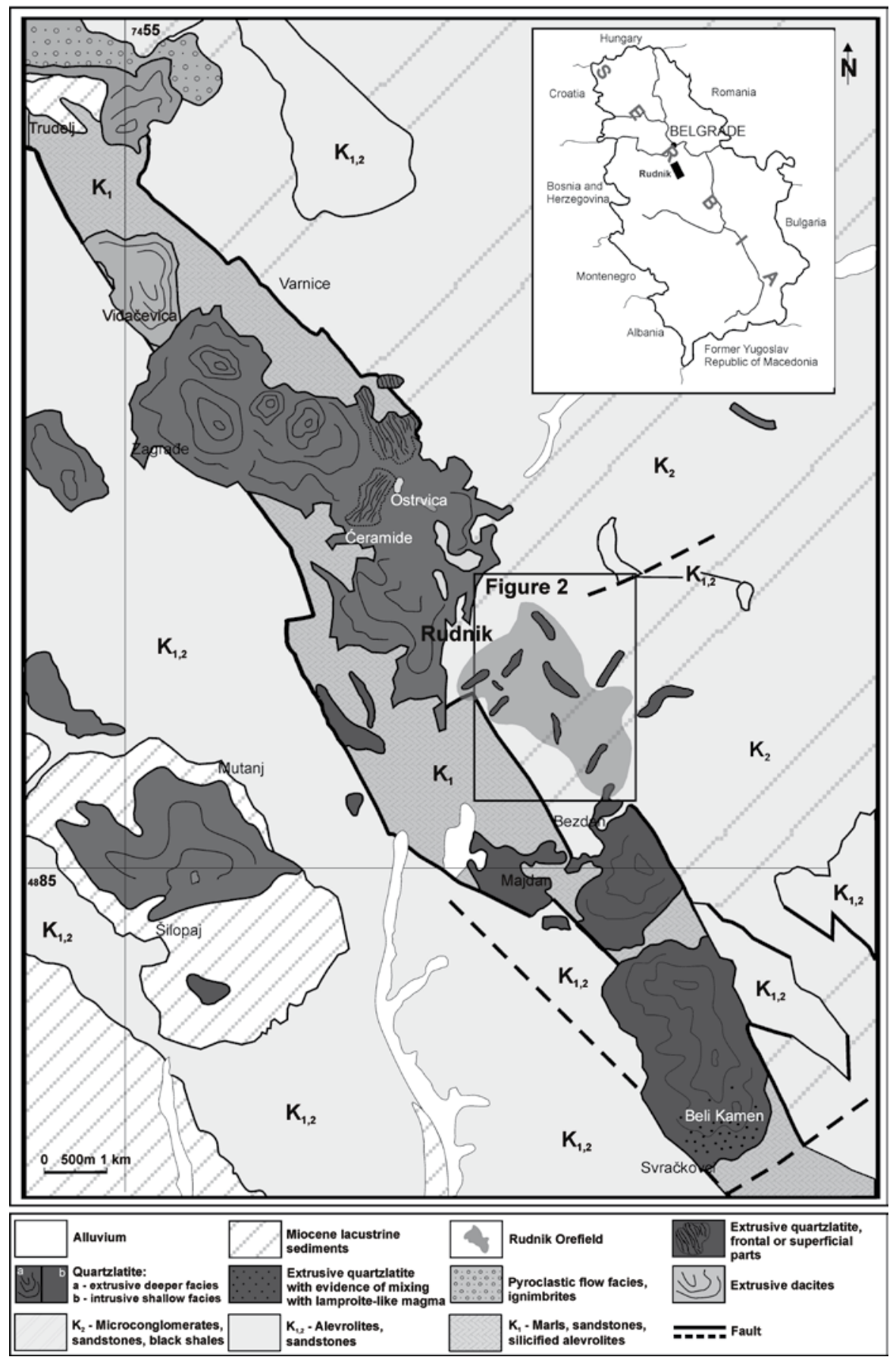

Figure 1. A geological-volcanological map of the Rudnik Mts. volcano-intrusive complex; the map is produced according to the Basic Geological Map 1:100.000, Sheets Gornji Milanovac (FILIPOVIĆ et al., 1978) and Kragujevac (BRKOVIĆ et al., 1980).

cesses and the formation of ore deposits remain poorly constrained.

In this paper we focus on the Rudnik Mts. volcano-intrusive complex that is situated in the very central part of the SerboMacedonian metallogenic province. It is our opinion, that this area is where the relationship between the magmatic evolution and mineralization is very clear, albeit still insufficiently known. So far, there is only a simplistic view about the general contemporaneity of the Cenozoic volcanism and mineralization (e.g. TOŠOVIĆ, 1997, 2000; POPOVIĆ \& UMELJIĆ, 2015). By reporting and discussing new radiometric age data, petrographic and volcanological observations and data on ma- jor and trace element whole rock concentrations, we try to reconstruct the magmatic evolution of the complex in unprecedented detail. We offer a volcanological model according to which the mineralization processes were genetically related to a younger igneous event that itself was controlled by magma mixing processes.

\section{REGIONAL GEOLOGY AND GEOTECTONIC SETTING}

It is widely accepted that the general geotectonic setting of the central Balkans was principally related to the formation, evolution and closure of the Mesozoic (Neo-)Tethys (see SCHMID et al., 2008; ROBERTSON et al., 2009; CVETKOVIĆ et al., 2016). Cenozoic geodynamics of this area evolved after the final consumption of Tethyan relicts, and this geodynamic regime is still active today. The final Tethyan closure gave rise to the consolidation of the complex Dinaride - Albanide - Hellenide - Carpathian - Balkan section of the larger Alpine-Himalayan orogenic belt. The orogenic processes were controlled by continuous N- to NW-directed movements of the Adria plate that acted as an African promontory. Albeit generally compressive, this geodynamics involved regional-scale plate reorganizations, and this made it possible for certain regions to evolve into strikeslip or even purely extensional tectonic styles. These geotectonic regimes, which were highly variable on the regional to local scale, were responsible for the formation of Cenozoic magmatism and the accompanying continental depositional systems along this orogen.

The Cenozoic magmatism of the central Balkan Peninsula developed over a basement mostly composed of remnants of the Tethyan lithosphere and crust. These remnants occur along a mega-suture composed of dismembered ophiolite thrust sheets, fragments of the underlying metamorphic basement of distal African plate, lithologically strongly heterogenous accretionary prism assemblages and various overlying overstep sequences, mainly flysches.

The Rudnik Mts. volcano-intrusive complex is located in central Serbia, around $80 \mathrm{~km}$ south of Belgrade (see inset in Figure 1). It is a NNW-SSE elongated area that predominantly consists of two large masses of volcanic and shallow intrusive facies and an orefield located in-between (Figures 1 and 2). The immediate basement of the complex is com- 


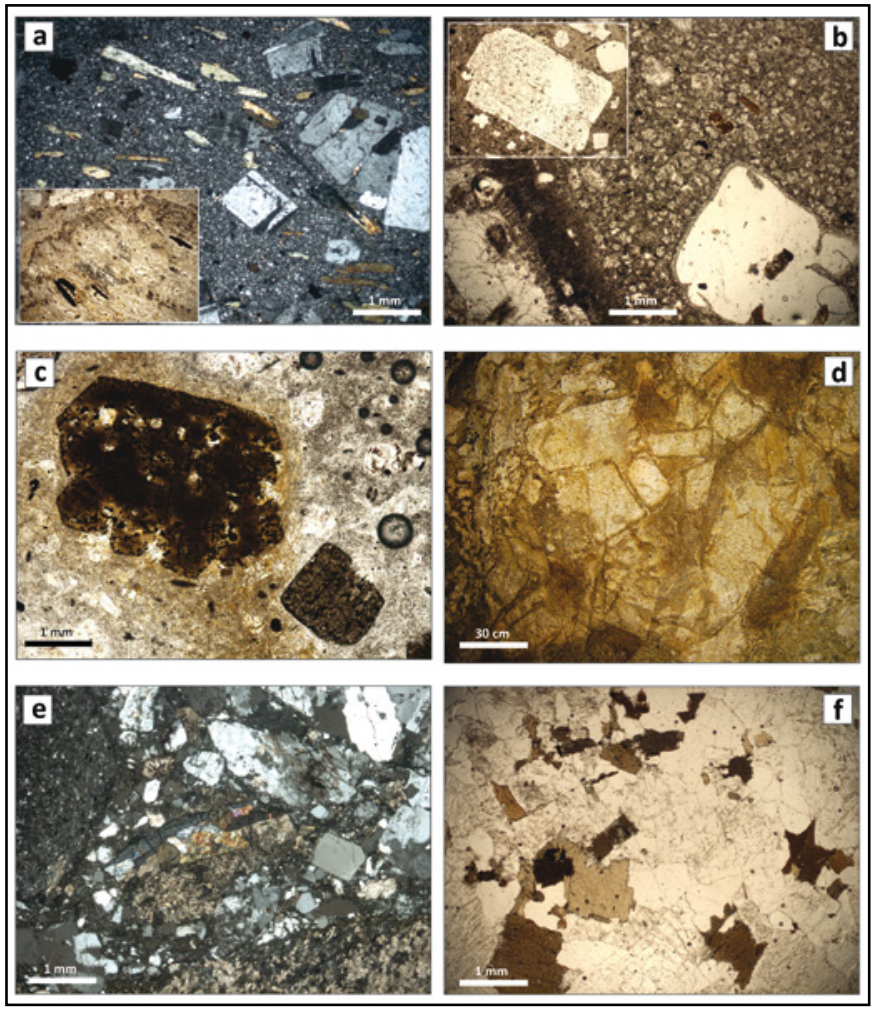

Figure 2. Petrography of various igneous rocks of the Rudnik Mts. volcano-intrusive complex. A) Photomicrograph of holo- to hypocrystalline porphyritic dacite (Vidačevica quarry); the inset showing a partially digested upper-crustal xenolith from the same dacite; B) Photomicrograph of coarsely porphyritic quartzlatite of extrusive facies (Ćeramide quarry); note the presence of a partially exposed large sanidine phenocryst (lower left) and an embayed quartz phenocryst (lower right); the groundmass is micropoikilitic and can be misinterpreted for holocrystalline (see text for further explanations); the inset shows a euhedral and sieved plagioclase phenocryst from the same rock; C) Partially resorbed biotite with sagenite inclusions (shallow intrusive quartzlatite); D) Mostly monomict hydraulic-hydrothermal breccias spatially associated with mineralization (underground mine); note that quartzlatite fragments are distinctively angular and mineralized along their margins, E) Photomicrograph of a polymict hydraulic-hydrothermal breccia (underground mine); F) Photomicrograph of monzogranite taken from a borehole that cut strongly polymict hydraulic-hydrothermal breccia.

posed of various Cretaceous flysch sediments that range in age from the Barremian-Aptian to the Turonian-Senonian. Below these sediments the basement is represented by $\mathrm{Ju}-$ rassic peridotites and serpentinites. The flysch deposits are products of various turbiditic sequences represented by alternating greywacke, siltstones and shales. The terrigenous series contains numerous limestone olistoliths (FILIPOVIĆ et al., 1978; BRKOVIĆ et al., 1980).

The volcanic rocks are temporarily associated with Oligo-Miocene sediments of the Gornji Milanovac lacustrine basin. The basin belongs to the Dinaride Lake System that represents a line of NNW-SSE elongated intramontane basins. The basins are associated with either steeply dipping normal faults (MAROVIĆ et al., 1999) or the formation of metamorphic core complexes along low-angle normal faults (MATENCO \& RADIVOJEVIĆ, 2012). The sediments of the Gornji Milanovac basin are represented by fresh water
Middle Miocene marginal facies conglomerates that grade into dark-reddish sandstones (FILIPOVIĆ et al., 1978). The terrigenous material contains abundant volcanic detritus that most likely originated by reworking of the rocks of the adjacent Rudnik Mts. volcano-intrusive complex.

\section{SAMPLING AND ANALYTICAL TECHNIQUES}

\subsection{K-Ar AGES}

Four K-Ar analyses of biotite and two of K-feldspar mineral separates, as well as one K-Ar analysis of an unspecified mixture of mafic minerals were undertaken in the Laboratory for K-Ar age dating of the Institute for Nuclear Research of the Hungarian Academy of Sciences in Debrecen (Hungary). Mineral separation involved crushing of whole rock samples and sieving to obtain the appropriate fraction. The separation was performed using a Franz magnetic separator and heavy liquid separation. Potassium concentrations were determined using flame photometry while applying an $\mathrm{Na}$ buffer and Li internal standard as well as Asia 1/65, LP6, HD-B1, GL-O inter-laboratory standards. The samples were treated in an Argon extraction line using RF fusion in molybdenum crucibles. A ${ }^{38} \mathrm{Ar}$ spike was added using a gas pipette system and the gas cleaning was done using Ti and SAES getters and liquid nitrogen traps. Ar isotope ratios were measured in the static mode, using a $15 \mathrm{~cm}$ radius magnetic sector mass spectrometer. Details about the instruments and methods can be found in BALOGH (1985). The radiometric ages were calculated according to the atomic constants of STEIGER \& JAEGER (1977). Analytical errors represent one standard deviation, i.e. $68 \%$ analytical confidence level.

\subsection{U-Pb ZIRCON DATING}

Uranium, thorium and lead isotopes were analysed using a ThermoScientific Element 2 sector field (SF)-ICP-MS system coupled to a Resolution M-50 (Resonetics) $193 \mathrm{~nm} \mathrm{ArF}$ excimer laser (ComPexPro 102F, Coherent) system at Goethe-University Frankfurt. Data were acquired in timeresolved peak-jumping pulse-counting/analogue mode over 356 mass scans, with a $20 \mathrm{~s}$ background measurement followed by 21 s sample ablation. Details about measurement conditions can be found in GERDES \& ZEH (2009).

\subsection{MAJOR AND TRACE ELEMENT ANALYSES}

Major oxides and trace element analyses were carried out in the ACME Laboratories Ltd. Vancouver, Canada. Concentrations of major element oxides were determined by ICP atomic emission spectrometry, with detection limits of approximately $0.001-0.04 \%$ (accuracy $2-5 \%$ ), whereas trace element and rare earth elements (REE) concentrations were measured using ICP-mass spectrometry (detection limits 0.01-0.5 ppm, accuracy $10-15 \%$ or better for trace elements and $1-5 \%$ for REE). STD SO-17 was certified inhouse against 38 Certified Reference Materials including CANMET SY-4 and USGS AGV-1, G-2, GSP-2 and W-2 (KARSLI et al., 2007). The analyses are considered accurate within the limits for major elements. 


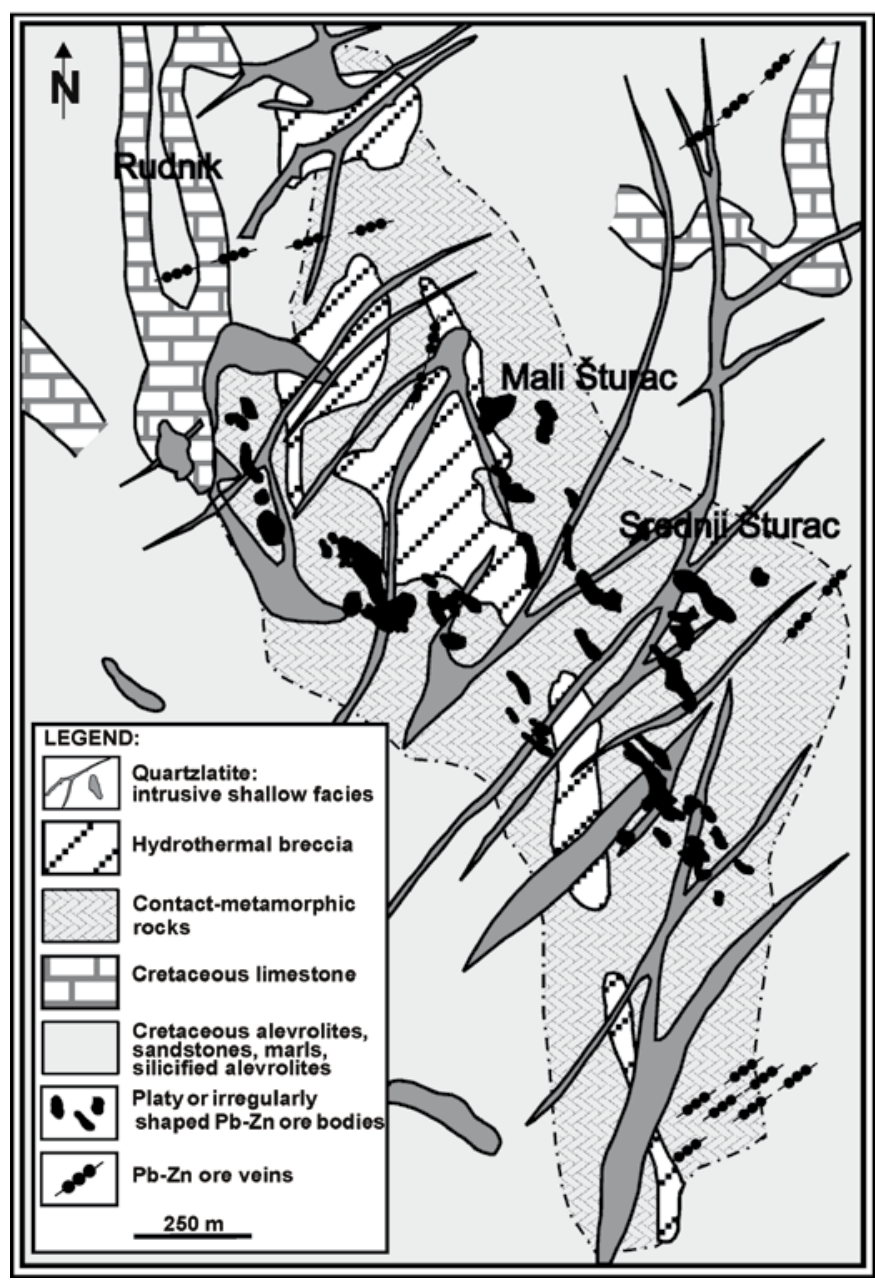

Figure 3. A geological sketch (RADULOVIĆ \& ERIĆ, 1997) showing the spatial distribution of rock facies and orebodies within the Rudnik Mts. Orefield.

\section{RESULTS}

\subsection{FIELD OBSERVATIONS AND ROCK PETROGRAPHY}

The following volcanic facies comprise the wider area of the Rudnik Mts. volcano-intrusive complex: 1) extrusive and shallow intrusive dacite and andesite, 2) extrusive and shallow intrusive quartzlatite, 3) monzogranite, 4) quartzlatiterhyodacite pyroclastic rocks, and 5) basaltoid rocks. The spatial distribution of the most abundant volcanic facies is given in the simplified geological-volcanological map (Figure 1). In the following text we present the major petrographic and volcanological characteristics of the above listed rock facies that are grouped according to their radiometric age and geochemistry (see below). In addition, the spatial distribution of ore bodies within the Rudnik Mts. Orefield is illustrated in Figure 3 and a short description of mineralization types is given in subsection 4.1.6.

\subsubsection{Extrusive and shallow intrusive dacite and andesite}

Dacite and andesite rocks occur as shallow intrusive facies in the north-westernmost part of the complex, and are best exposed in the Vidačevica quarry (see Figure 1). Petrographically very similar dacite-andesite rocks are also found in boreholes near Stragari, outside of the complex, around $10 \mathrm{~km}$ east of the Rudnik Mts. Orefield. The rock mass in the Vidačevica quarry is generally polygonally jointed but along its periphery the rocks are platy jointed and display a pronounced fluidal fabric. The dacite is hollocrystalline porphyrytic and polyphyric ( $>50$ vol. $\%$ of phenocrysts) with seriate textures and consists of phenocrysts of plagioclase, quartz, biotite and amphibole, and microphenocrysts of the same minerals (Figure $2 a)$. Quartz is relatively rare, subhedral and often shows embayments as effects of resorption. Biotite is slightly more abundant than amphibole. They are very fresh and show typical pleochroism, whereas opacitization is only weakly developed. These volcanic rocks contain abundant crustal xenoliths (Figure 2a, inset). The xenoliths range from a few $\mathrm{cm}$ to a few $\mathrm{dm}$ in length and represent fragments of various schists, gneiss and amphibolites. Some xenoliths show the effects of contact-metamorphism along their margins.

\subsubsection{Extrusive and shallow intrusive quartzlatite}

Extrusive volcanic facies of quartzlatitic composition are predominant in the Rudnik Mts. volcano-intrusive complex. There are two large quartzlatitic masses that extend in a NNW-SSE direction and are separated by the Rudnik Mts. Orefield (Figure 1). In addition, there is a relatively large volcanic mass situated several kilometres east of the Rudnik Mts. Orefield.

The extrusive quartzlatites are exposed in many places and in particular in the Ćeramide active quarry. They are platy to polygonally jointed and often show evidence of planparallel and fluidal fabric. The roof parts of these extrusions are represented by highly porous rocks and have a tuff-like appearance. This was the reason that these rocks were erroneously interpreted as pyroclastic deposits (FILIPOVIĆ et al., 1978). The quartzlatite is porphyritic with variable phenocryst contents, but rarely above 30 vol.\%. The phenocrysts are represented by quartz, plagioclase, sanidine, biotite and amphibole with apatite, zircon and opaques as accessories. The matrix is hypocrystalline and in some places the volcanic glass is replaced by micropoikilitic fine-grained textures (LOFGREN, 1971), which can easily be misinterpreted as holocrystalline (Figure 2b). Quartz is subhedral and often shows well developed embayments. Plagioclase is euhedral and tabular in shape and it very often exhibits so-called 'sieved' textures defined by the presence of tiny drop-like inclusions of glass (Figure $2 b$, inset). Such textures are commonly explained by partial resorption of plagioclase crystals, which implies nonequilibrium conditions during crystallization (NELSON \& MONTANA, 1992). Sanidine is ubiquitously present, but it can be as $10 \mathrm{~cm}$ crystals and, therefore, rarely present in thinsections (Figure $2 \mathrm{~b}$ ). It is pale pinkish to white in colour and often shows typical Carlsbad-type twinning. Biotite occurs in the form of prismatic flakes, usually elongated in one direction, sometimes showing evidence of plastic deformation. It shows pleochroism in dark-red-brown colours. In some samples biotite contains needle-like sagenite inclusions and those biotite flakes usually show the effects of resorption (Figure 2c). Amphibole appears in prismatic and euhedral to subhedral phenocrysts. In some samples it is more abundant than biotite, in others it is almost totally lacking. One of the most important petrographic features of these quartzlatites is the presence of rounded to subrounded mafic microgranular en- 
claves. The enclaves are lamprophyric in character and are rich in dark mica, sometimes accompanied by amphibole. In the south-eastern part of the complex a composite dome-like body composed of dacite - quartzlatite - leucominette occurs. This rock association is described in detail by PRELEVIĆ et al. (2000, 2001a).

Shallow intrusive quartzlatite occurs as a few metres to a few tens of meters thick discordant dykes or concordant silllike bodies, which are mostly, emplaced within Cretaceous flysch sediments (Figures 1 and 3). The dykes often appear on the surface, but they are abundant in the Rudnik Mts. Orefield, in particular in the underground mine. The Cretaceous sediments show the effects of contact-metamorphism, but without regularities between the contact-metamorphic grade and the thickness and orientation of these quartzlatite shallow intrusions. The contact-metamorphic rocks range in composition from only slightly thermally metamorphosed sandstones up to garnet- and axinite bearing skarns. Shallow intrusive quartzlatites are petrographically almost indistinguishable from the extrusive quartzlatites described above. They are hypo- to holocrystalline porphyritic in texture and show variable abundance of phenocrysts. Some dykes show chilled margins and are devoid of large sanidine phenocrysts.

Hydrothermal quartzlatite breccia represents a subgroup of shallow intrusive facies. They are spatially restricted to the Rudnik Mts. Orefield and are found both at the surface and in the underground mine, in the latter case in close contact with mineralization. They are clast-supported mostly monomict breccias with highly unsorted angular fragments that sometimes show jigsaw puzzle fit structures. The fragments are usually strongly altered and sometimes heavily mineralized, especially along the margins of the volcanic fragments (Figure $2 \mathrm{~d}$ ). The most important alterations are propylitization and silicification, whereas potassic alteration is subordinate. The fragments are cemented by highly variable material, from silicates, dominated by quartz and clay minerals through primary hydrothermal sulphides to supergene limonite.

Some breccias are polymict in character and consist of volcanic fragments of different textures, mineral compositions and the extent of alteration and mineralization as well as of those of adjacent contact-metamorphosed flysch sediments (Figure 2e). The polymict breccia sometimes contains remarkably fresh fragments of equigranular rocks similar to monzogranite that is a separate lithology described below.

\subsubsection{Monzogranite}

The presence of plutonic rocks of monzogranite composition was first reported by BRKOVIĆ et al. (1980) who described weak outcrops within the Rudnik Mts. Orefield. These outcrops most likely represent the internal portions of thicker shallow quartzlatite intrusions. During our field campaign these rocks are found exclusively as individual fragments in the polymict hydrothermal breccia described above.

The plutonic rocks show uniform petrographic characteristics and mineral compositions by displaying medium- rarely fine-grained hypidiomorphic granular texture and massive and homogeneous fabric (Figure 2f). The monzogranite is composed of plagioclase, quartz, potash feldspar, biotite and subordinate amphibole. Plagioclase is subhedral and, along with biotite and amphibole, constitutes the main crystal network, whereas the interstitial spaces are filled by quartz and perthitic potash feldspar. Sphene, apatite, opaques and zircon are the most important accessory minerals. Rare fragments of these rocks exhibit inequigranular texture with larger potash feldspar oikocrysts, which makes these rocks petrographically similar to the shallow intrusive quartzlatite.

\subsubsection{Quartzlatite-rhyodacite pyroclastic rocks}

These rock facies occur only in the most northwestern part of the complex (Figure 1). In the wider area, they appear as irregular patches of volcaniclastic rocks that usually overlie Cretaceous flysch deposits and are transgressively covered by Mio-Pliocene lacustrine strata. They are not addressed in detail in this study, but according to our field observations in the most northwestern part of the complex as well as according to data from the Basic Geological Map of the SFR of Yugoslavia, Sheets Kragujevac and Gornji Milanovac (FILIPOVIĆ et al., 1978; BRKOVIĆ et al., 1980, respectively), these rocks correspond to rarely preserved unwelded to welded ignimbrites. More rarely, they represent various reworked and redeposited primary pyroclastic deposits (TERZIĆ \& TERZIĆ, 1972). Dense juvenile fragments of these pyroclastic rocks are porphyritic with glassy to hypocrystalline groundmass and are petrographically very similar to the extrusive quartzlatites described earlier. Although the juvenille pyroclasts only rarely contain large sanidine phenocrysts, they are characterized by sieved plagioclase phenocrysts and often contain partially resorbed biotite and hornblende.

\subsubsection{Basaltoid rocks}

Basaltoid rocks of the wider Rudnik Mts. complex are studied petrologically in detail by CVETKOVIĆ et al. (2004) and PRELEVIĆ et al. (2005). These rocks have negligible volumes in comparison to the acid to intermediate rocks described above, and mostly occur as several metre thick dykes and sills or lava plugs, rarely as lava flows. They range in composition from calc-alkaline, medium- and high-K calcalkaline basalts to those showing ultrapotassic affinity and displaying minette or lamproite petrographic characteristics. As previously mentioned above, PRELEVIĆ et al. (2000, 2001a) reported the presence of hybrid rocks in the southeastern part (Beli Kamen) of the complex and called them leucominette.

\subsubsection{The Rudnik Mts. Orefield}

Presenting detailed characteristics of the Rudnik Mts. polymetallic deposit is beyond the scope of this study. Therefore, in this subsection we only briefly summarize what is generally known about this complex deposit (MILIĆ, 1972; JANKOVIĆ et al., 2003; TOŠOVIĆ, 1997, 2000).

As it is shown in Figure 3, the Rudnik Mts. Orefield is an elongated area composed of contact metamorphosed clastic and carbonate flysch sediments. The contact metamorphic zone hosts several elongated areas of hydrothermal breccia and numerous quartzlatite dyke-like shallow intrusive facies. These rock facies, which have already been described above, are closely spatially associated to numerous orebodies, which indicates that mineralization is most likely associated with the same structures that were used by the quartzlatite magma. 


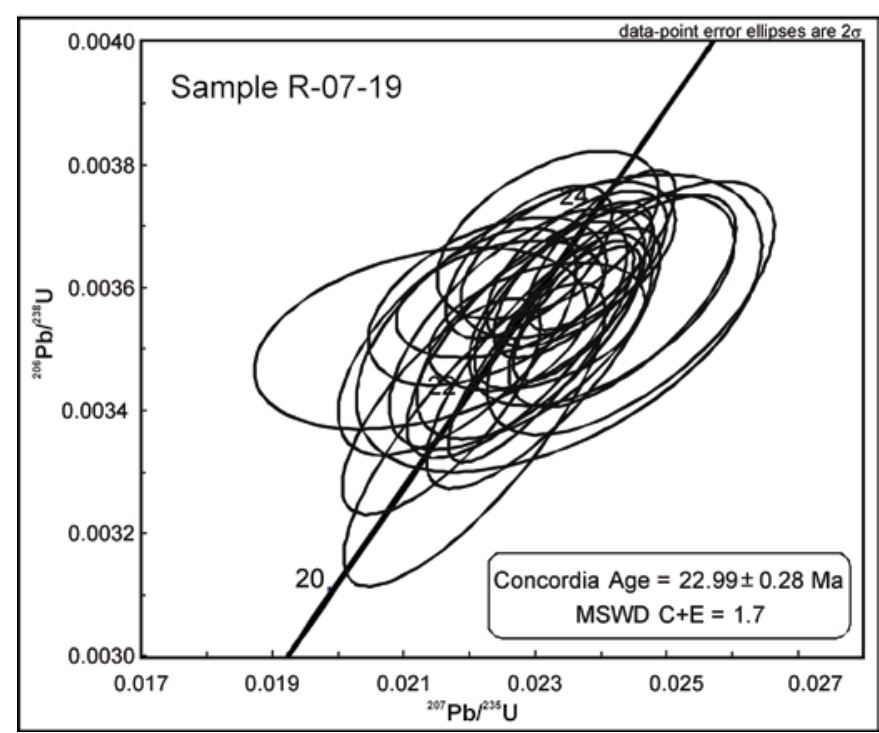

Figure 4. Concordia U-Pb diagram for zircons from a hydrothermally altered and mineralized sample R-19.

The orebodies have variable morphology, most often, they are platy to vein- and lens-like. The orebodies range in size from $10 \mathrm{~m}^{3}$ to $7 \times 103 \mathrm{~m}^{3}$ or even up to $3 \times 105 \mathrm{~m}^{3}$. They display two general modes of occurrence: 1) gently dipping, up to $2 \mathrm{~m}$ thick lenses that can be traced for 150-350 m; they are mainly spatially associated to contact-metamorphosed limestone blocks within the flysch sediments, and 2) predominantly high dipping platy bodies located within the subvolcanic quartzlatites (MILIĆ, 1972).

TOŠOVIĆ (1997) recognized roughly two major stages of mineralization processes in this area. The first that occurred was skarn mineralization associated in time with formation of the contact metamorphic rocks. This mineralization is only locally developed but in some places contains significant amounts of scheelite, magnetite and subordinate cassiterite (STOJANOVIĆ et al., 2006). The skarn mineralization is overprinted by the formation of hydrothermal replacements and structure-controlled veins and lenses. During this stage the most important orebodies originated. The mineralogy of these orebodies is dominated by pyrrhotite which often shows transitions to Ni-bearing pyrrhotite, sphalerite, galenite, chalcopyrite and subordinate arsenopyrite. The $\mathrm{Pb}-\mathrm{Zn}$ grade in these ore bodies is highly variable but mostly around $7-8 \%$. In addition, the ore contains up to $0.5 \%, 150 \mathrm{ppm}$ and 450 ppm of $\mathrm{Cu}, \mathrm{Ag}$ and $\mathrm{Bi}$, respectively (JANKOVIĆ et al., 2003).

\subsection{K-Ar AND U-Pb RADIOMETRIC AGES}

Seven so far unpublished K-Ar age determinations and 11 $\mathrm{K}-\mathrm{Ar}$ ages published earlier are reported together in Table 1. A mixture of mafic minerals of the hydrothermally altered sample R-19 revealed the largest relative error of $>20 \%$. Because this sample is also characterized by low potassium contents and a low concentration of radiogenic argon, the obtained age of $39 \pm 9.2 \mathrm{Ma}$ is discarded. However, given that this sample was very important with respect to defining the maximum age of the mineralization, zircons from the sample were analyzed by LA-ICP-MS on U-Pb. The results shown in Figure 4 gave a concordia $\mathrm{U}-\mathrm{Pb}$ age of $22.99 \pm 0.28 \mathrm{Ma}$.

All other biotite and K-feldspar separates gave K-Ar ages with relatively small errors $(< \pm 1.13 \mathrm{Ma})$, consequently, their ages are reliable and considered to be close to the time of crystallization. There are two groups of ages. One is Oligocene and was obtained on the extrusive dacite from the Vidačevica quarry $(35.30 \pm 1.09 \mathrm{Ma})$ and on the shallow intrusive andesite in a borehole near Stragari $(35.69 \pm 1.13 \mathrm{Ma})$. The other group is represented by the latest Oligocene to Early Miocene ages (roughly 19-23 Ma). They are obtained by various volcanic quartzlatitic facies that include massive $(19.02 \pm 0.59 \mathrm{Ma})$ to porouse $(20.44 \pm 0.67 \mathrm{Ma})$ extrusive quartzlatites, unaltered quartzlatite, breccia from the underground mine $(22.97 \pm 0.72 \mathrm{Ma})$, and monzogranite from a borehole in the Rudnik Mts. Orefield (23.14 $\pm 0.73 \mathrm{Ma})$.

Such a bimodal distribution is observed in other available $\mathrm{K}-\mathrm{Ar}$ ages. These data also show two ranges, one between 29

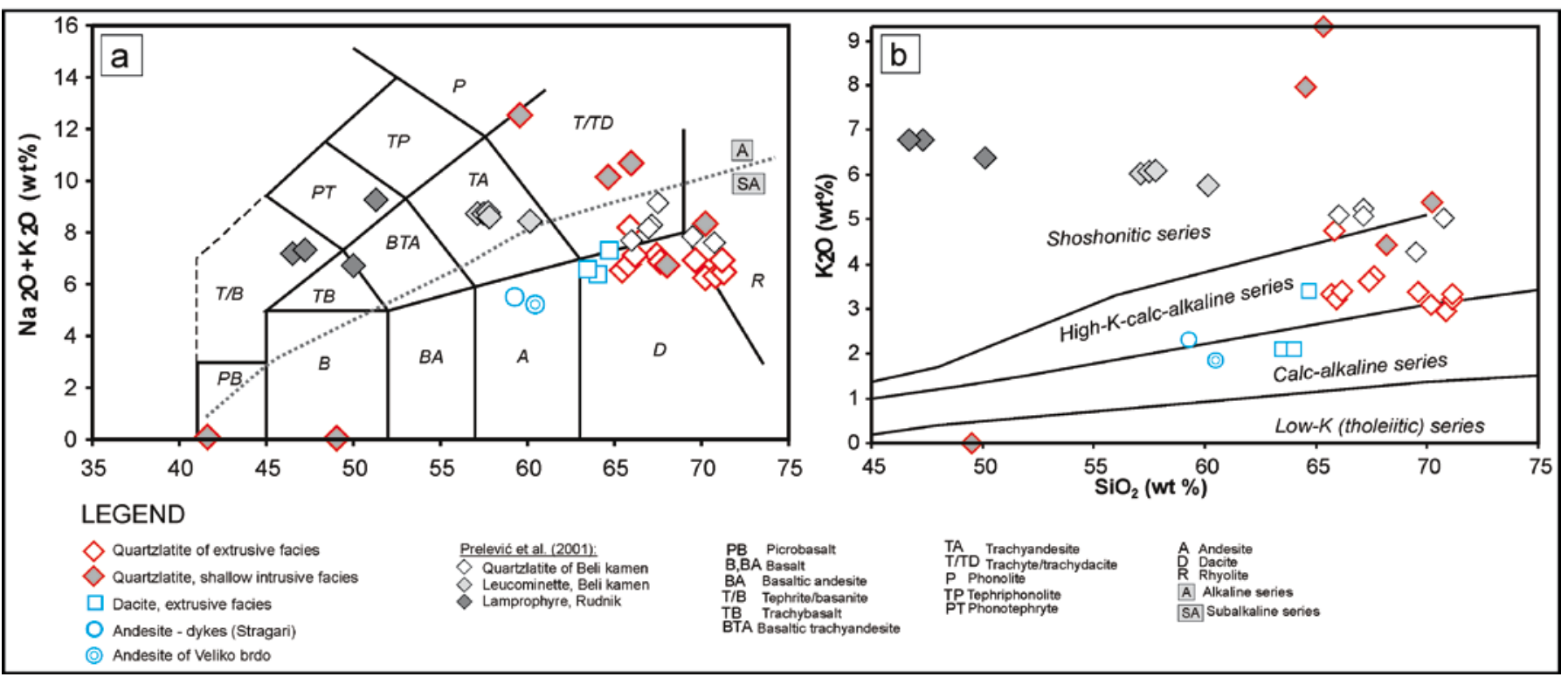

Figure 5. Total alkali vs silica classification diagram (A - LE BAS et al., 1986) and the $\mathrm{SiO}_{2} \mathrm{vs}_{2} \mathrm{O}$ diagram

(B - PECCERILLO \& TAYLOR, 1976) for studied rocks of the Rudnik Mts. volcano-intrusive complex. 


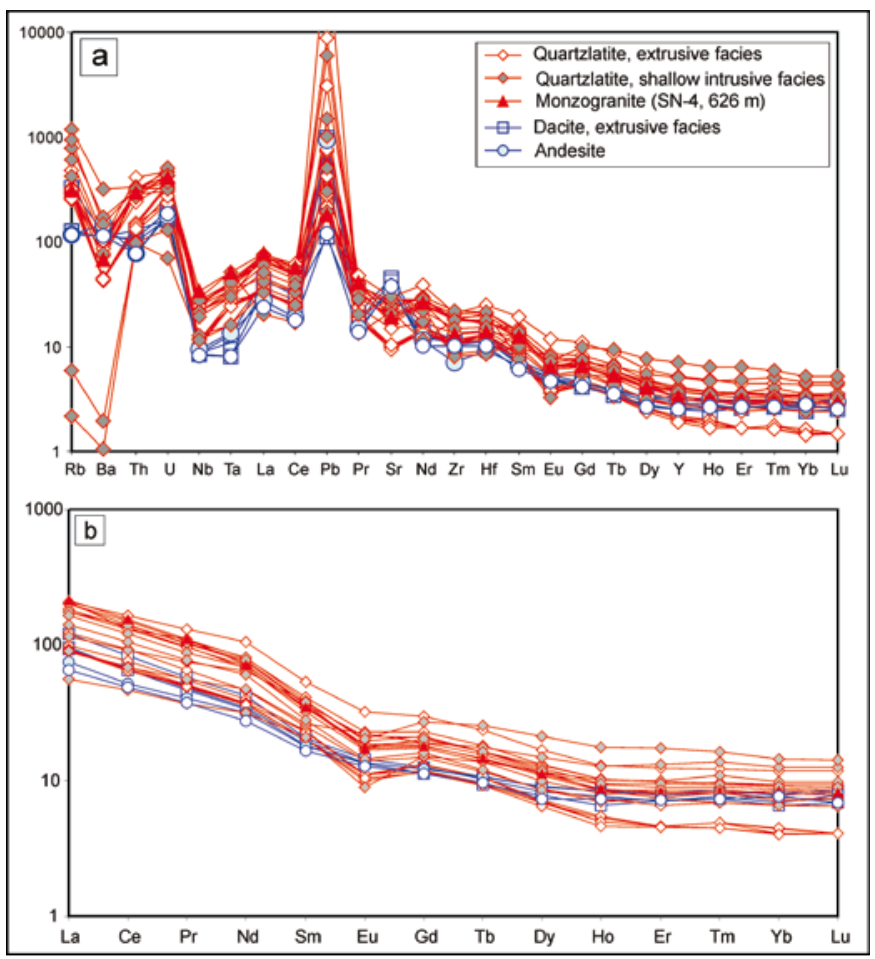

Figure 6. Primitive mantle- (a) and chondrite- (b) normalized trace element and REE concentrations for the studied rocks of the Rudnik Mts. volcano-intrusive complex; coefficients for normalization after McDONOUGH \& SUN (1995).

$\mathrm{Ma}$ and $32 \mathrm{Ma}$ and another that ranges from $26 \mathrm{Ma}$ to $19 \mathrm{Ma}$. One K-Ar age obtained on olivine trachyte from Boljkovac (TERZIĆ \& SVEŠNJIKOVA, 1991), is remarkably older than all the known ages of Cenozoic igneous rocks of this area, and must be excluded. Although it is not easy to exactly compare the lithologies that were investigated in this study and those for which the older K-Ar age determinations exist, the following conclusions can be derived. Firstly, dacite-andesite rocks are Oligocene and are systematically older than all facies of quartzlatitic composition, which are Early Miocene in age. Secondly, the monzogranite originated more or less contemporaneously with the quartzlatite. Thirdly, mineralization most likely formed immediately after the shallow intrusive quartzlatite had crystallized.

\subsection{WHOLE ROCK GEOCHEMISTRY}

So far unpublished whole rock major and trace element concentrations, including REEs, for the various Rudnik Mts. igneous rocks are reported in Table 2. Data mainly for basaltoid and leucominette rocks are taken from the literature (PRELEVIĆ et al., 2001a, 2005; CVETKOVIĆ et al., 2004) and are plotted in diagrams below.

According to the total alkali vs silica classification diagram (LE BAS et al. 1986) and the $\mathrm{SiO}_{2}$ vs $\mathrm{K}_{2} \mathrm{O}$ diagram (PECCERILLO \& TAYLOR, 1976) (Figures 5a, b) it is evident that: 1) the Rudnik Mts. magmatic rocks predominantly correspond to acid to intermediate rocks with silica contents above $55 \mathrm{wt} . \%$, with subordinate intermediate to basic rocks, 2) most rocks correspond to subalkaline and to high- to medium-K calc-alkaline trend, with the exception of basaltoid rocks that are ultrapotassic to shoshonitic in character (FOL-
EY et al., 1987), 3) the rocks petrographically classified as quartzlatites are mainly medium-K calc-alkaline and plot along the line between the dacite and rhyolite fields, with some samples stretching into the trachydacite field, 4) the samples petrographically determined as monzogranite plot very close to the quartzlatites, 5) four samples plot in the andesite and dacite field which is in accordance with their petrography, and 5) two samples of hydrothermally altered quartzlatite have very low silica and alkali contents and this most likely does not reflect their primary composition. In addition, the dacite and andesite samples show slightly higher $\mathrm{Al}_{2} \mathrm{O}_{3}$ (mostly $>15$ wt. \%) and $\mathrm{CaO}$ (mostly 3-5 wt.\%) contents in comparison to the quartzlatitic rocks $\left(\mathrm{Al}_{2} \mathrm{O}_{3}\right.$ mostly $<15$ wt.\%, and $\mathrm{CaO}$ mostly $<3$ wt.\%).

In Figures $6 \mathrm{a}, \mathrm{b}$ primitive mantle-normalized trace element and chondrite-normalized REE concentrations (McDONOUGH \& SUN, 1995) are plotted. The spider diagram patterns of all the studied rocks are fairly similar and are characterized by spiked large ion lithophile elements as well as light REE-enriched shapes. These are typical patterns of rocks crystallized from magmas in which petrogenesis continental crustal material has been largely involved. Despite this generally similar geochemical signature, the studied samples show subtle, but observable differences. For instance, all rocks that belong to quartzlatite facies show identical geochemical patterns, and these are remarkably similar to the pattern shown by a monzogranite sample. On the other hand, dacite and andesite rocks exhibit mutually indistinguishable trace element and REE patterns that are slightly different from those shown by quartzlatites. Namely, the pattern of dacite and andesite rocks shows a distinctive Sr positive anomaly, but lacks negative anomalies for $\mathrm{Ba}$ and $\mathrm{Eu}$ and there is a relatively flat pattern of heavy REEs. For instance, Dy/Lu is $<11$ and $>13$ in the dacite-andesite and in the quartzlatite, respectively.

\section{DISCUSSION}

The field and petrographic observations presented above as well as new and previously published radiometric and geochemical data provide conditions for better understanding the origin and evolution of the Rudnik Mts. volcano-intrusive complex. Previously, there was a strong mismatch between a highly variable rock petrography and volcanic facies, on one side, and fragmentary information about petrology and geochemistry and the radiometric age of the volcanic and intrusive rocks. In the following discussion we first establish the relationship between radiometric ages and the inferred rock compositions, then, we discuss the younger quartzlatite volcanic event as the most significant in terms of the volume of volcanic products and with respect to its significance for mineralization processes. Finally, we propose a simplified volcanological model for the entire Rudnik Mts. volcano-intrusive complex.

\subsection{THE TIME-COMPOSITIONAL FRAMEWORK OF THE RUDNIK MTS. VOLCANO-INTRUSIVE COMPLEX}

The available radiometric analyses indicate that there is a coupling between the age and the composition of the Rudnik Mts. igneous rocks. The extrusive to subvolcanic dacite and andes- 

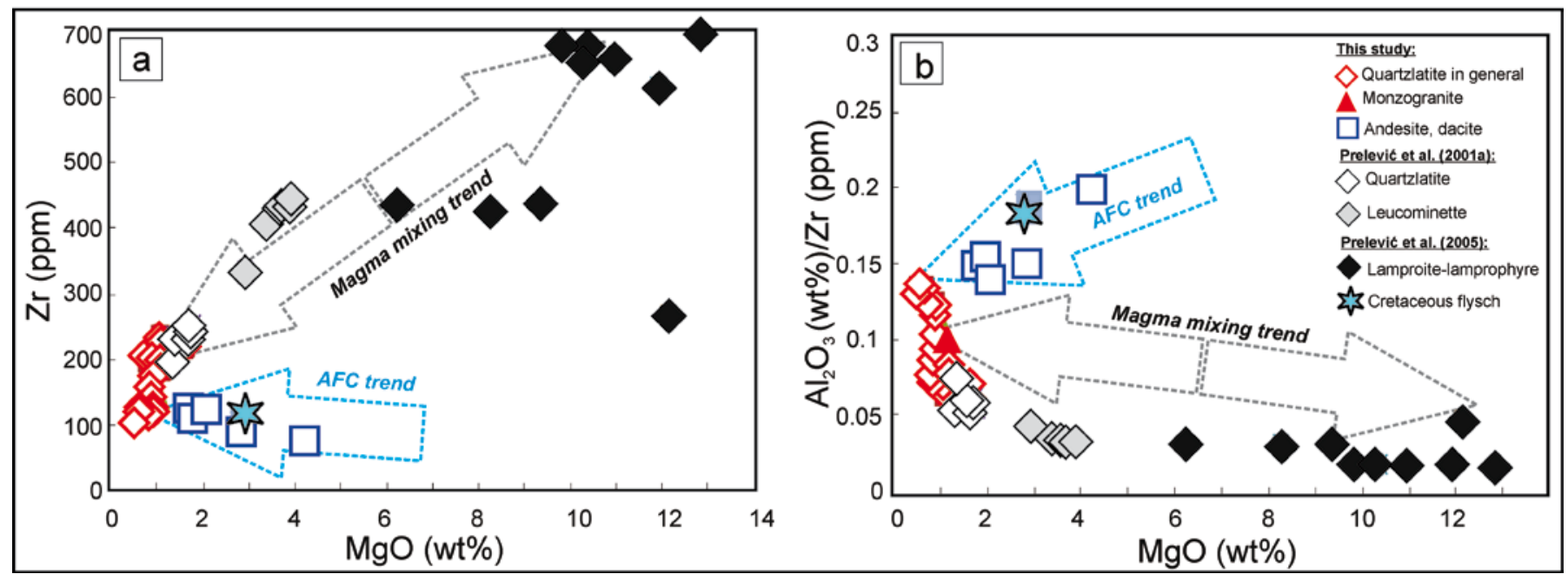

Figure 7. Plots of $\mathrm{MgO}$ (wt.\%) vs $\mathrm{Zr}(\mathrm{ppm})$ and $\mathrm{MgO}$ (wt.\%) vs $\mathrm{Al}_{2} \mathrm{O}_{3}$ (wt.\%)/Zr (ppm) for unaltered rocks of the Rudnik Mts. volcanointrusive complex.

ite rocks, which are strongly subordinate in volume, show an Oligocene age of around $35 \mathrm{Ma}$. This age is similar to an unpublished K/Ar age of around $32 \mathrm{Ma}$ (Table 1) obtained on a petrographically very similar dacite from Slavkovica, located around $15 \mathrm{~km}$ west of the Rudnik Mts. (TERZIĆ \& VUKOV, 1984). Alternatively, volcanic and shallow intrusive quartzlatite facies as well as monzogranite from a borehole are clearly younger and have radiometric ages ranging between $19 \mathrm{Ma}$ and $23 \mathrm{Ma}$. The U-Pb zircon age of $22.99 \pm 0.28 \mathrm{Ma}$ obtained from a strongly hydrothermally altered and mineralized hydrothermal quartzlatitic breccia delimits the maximum age of mineralization and suggests that formation of the ore deposit was temporarily and, most likely, also petrogenetically associated with the quartzlatites.

The available ages of basaltoid rocks of the wide Rudnik Mts. area range between $24 \mathrm{Ma}$ and $32 \mathrm{Ma}$ (CVETKOVIĆ et al., 2004; PRELEVIĆ et al., 2005), which suggests that basaltoid magmatism was likely active during both the afore-mentioned events. Although there are no radiometric ages of basaltoid rocks younger than $24 \mathrm{Ma}$, there is solid evidence that mafic magma similar in composition to lamprophyre-lamproite co-existed with acid melts during the younger volcanic event when most of the quartzlatite originated. In particular, much textural evidence, such as the presence of mafic microgranular enclaves, sieved plagioclase phenocrysts, co-existing phlogopite $\left(\mathrm{Mg} \#\left[\mathrm{molMg} / \mathrm{Mg}+\mathrm{Fe}_{\text {tot }}\right]\right.$ up to 0.91$)$ and biotite $(\mathrm{Mg} \#$ up to 0.61) (PRELEVIĆ et al., 2001a), partially resorbed mafic phenocrysts as well as the occurrence of large composite extrusions in the area of Beli Kamen (PRELEVIĆ et al., 2000, 2001a), imply that mixing between a lamprophyric to lamproitic magma and a dacitic melt has played a significant role in the quartzlatite petrogenesis. This can be taken as ample evidence that basaltoid magmatism was active up to the end of the complex formation. Moreover, it can be postulated that geodynamic conditions during the Oligocene favoured the emplacement of individual and distinct pulses of basaltoid magma, whereas those that were active at the beginning of the Miocene enabled injection of similar basaltoid melts into already existing reservoirs of acid magma (see MLADENOVIĆ et al., 2015).

\subsection{QUARTZLATITE VOLCANISM: THE LINK BETWEEN MAGMATISM AND MINERALIZATION}

The time and compositional constraints presented above demonstrate that the Rudnik Mts. volcano-intrusive complex is predominantly composed of various products of magma of quartzlatite composition, all of which formed roughly simultaneously $<23 \mathrm{Ma}$ ago. Furthermore, there are strong indications that these quartzlatite volcanic, subvolcanic and intrusive facies were emplaced via a continuous succession of volcanic events, which were ultimately followed by hydrothermal stages and precipitation of $\mathrm{Pb}$ $\mathrm{Zn}$ mineralization. It is also almost indisputable that magma mixing has played a crucial role in the volcanic events that produced the Rudnik Mts. quartzlatites. The petrographic evidence has already been listed above and here we discuss additional aspects that are closely related to rock geochemistry, volcanology and, supposedly, to mineralization processes.

Petrological and geochemical consequences of mixing between lamproite- and dacite-like magmas have already been recognized and explained in other Cenozoic provinces of the Balkan Peninsula. The most comprehensive study was by PRELEVIĆ et al., (2004) on the hybrid rocks from the Veliki Majdan area in western Serbia, suggesting that magma mixing may be a common process for lamprophyre formation. PRELEVIĆ et al. (2000, 2001a) described similar processes near Beli Kamen in the southeastern part of the Rudnik Mts. volcano-intrusive complex. They recognized petrographic and geochemical transitions between leucominette and the rhyodacite part of the extrusion and attributed this to hybridization. According to their model, hybridization occurred after a lamproite-like magma had invaded the base of an already stratified chamber with dacitic magma; this induced turbulent fountains and formation of more mafic leucominette facies. Similar magma mixing processes were reported in the adjacent Miocene Borač complex (CVETKOVIĆ \& PECSKAY, 1999; CVETKOVIĆ et al., 2001). Furthermore, they considered that the injection of lamproite-lamprophyre melts has served as a trigger for Plinian explosive activity.

The data from this study are insufficient to refine the model of PRELEVIĆ et al. (2001a) to any significant extent. However, our data can be used to illustrate relatively simple geochemical variations that imply magma mixing processes. Diagrams that show 


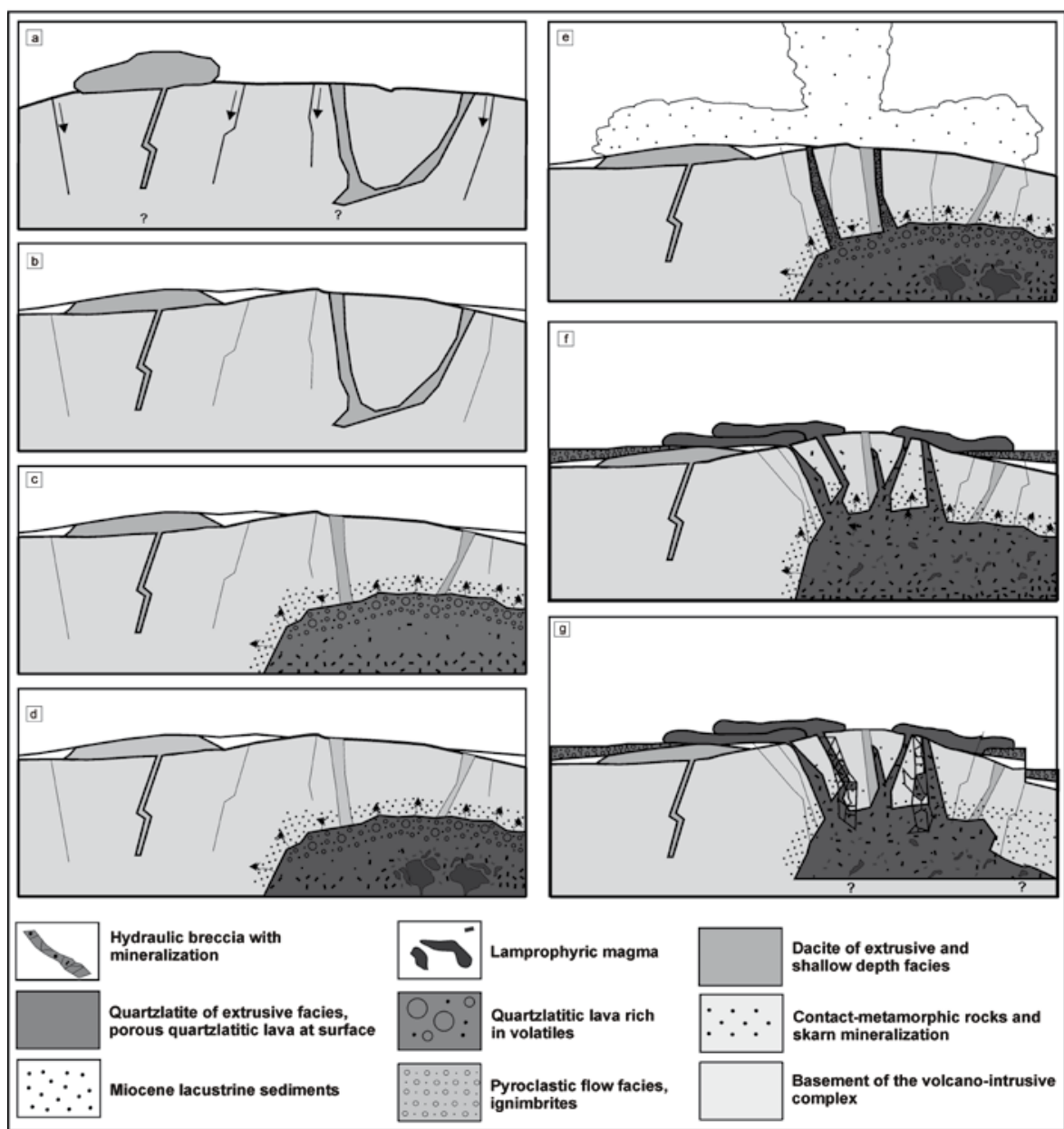

Figure 8. A simplified volcanological model for the Rudnik Mts. volcano-intrusive complex (see text for explanation).

different variation paths for dacite-andesite and quartzlatite rocks of the Rudnik Mts complex are given in Figures 7a, b. From the plots of $\mathrm{MgO}$ (wt.\%) vs $\mathrm{Zr}$ (ppm) and $\mathrm{MgO}$ (wt.\%) vs $\mathrm{Al}_{2} \mathrm{O}_{3}$ (wt.\%)/Zr (ppm) diagrams it is evident that: 1) dacite-andesite rocks plot close to upper crustal compositions reflected by the composition of Cretaceous flysch deposits, 2) these rocks form trends of increasing $\mathrm{Zr}$ contents and $\mathrm{Al}_{2} \mathrm{O}_{3} / \mathrm{Zr}$ ratios with decreasing $\mathrm{MgO}$ contents, which implies the effects of assimilation plus fractional crystallization processes (AFC), 3) these trends are distinct with respect to the trends shown by quartzlatites, leucominette and basaltoid (lamprophyre-lamproite) rocks, and 3) the latter trends suggest compositional mixing between melts similar in composition to the most evolved dacite (the continuation of the dacite-andesite trend) and basaltoid (lamprophyre-lamproite) melts. This is exactly what is suggested by both field and petrographic evidence.

These mixing processes had very important consequences with respect to volcanic activity and mineralization. First, as already mentioned, it most likely provided conditions for triggering large-scale explosive eruptions that produced widespread pyroclastic products. Second, the injection of water-laden lamprophyric-lamproitic melts may have delivered additional water to the resulting hybridized magma, and this could have been crucial for enabling secondary boiling, even in a magma that previously degassed via strong explosive activity. It can therefore be postulated that without these injections of mafic melts, the magma chamber would probably be emptied by explosions, but it would have occurred later and have not led to subsequent hydrothermal and mineralization phases. Finally, the mixing was responsible for the generation of a wide spectrum of volcanic facies and petrographic rock varieties. The volcanological and petrographic variability imposed great problems for earlier investigators, because their descriptions were overburdened by dozens of different rock varieties, such as: dacite, quartzlatite, rhyodacite, lamprophyre, lamproite, leucitite, leucite basanite, minette, kajanite, trachybasalt, trachyandesite, latite, trachyte, and so on and so forth. Such a 'flood' of petrographic names prevented them from understanding the rock petrogenesis in sufficient detail and to produce valid tectonomagmatic interpretations.

Our volcanological observations indicate that the breccia occurring in the Rudink Mts. Orefield most likely originated in response to hydraulic fragmentation events that are readily produced by subsurface decompression of fluids (e.g. CAS \& WRIGHT, 1987). PHILLIPS (1972) produced a model for these brecciation processes and for the formation of mostly subvertical, pipe-or dyke-like brecciated zones. Given that these breccias appear at many places on the surface, it is likely that at least some of them represented diatremelike structures that originated via phreatic explosions. The hydrothermal fluids that generated brecciation were also responsible for precipitating mineralization, and that is evident from the fact that ore is often deposited in the matrix of these breccias, i.e. some fragments are cemented by ore minerals. The presence of strongly polymict breccia can indicate that some of these rocks may be polyphase in origin and can be associated with tectonic processes as well. These processes can be responsible for the presence of equigranular monzogranite fragments within the polymict breccias.

The granular monzogranite facies probably represent parts of a presumably large unexposed magmatic body, whereas subvolcanic quartzlatitic bodies, which are found both in the underground mine and on the surface, can be apophyses of this intrusive.

\subsection{A SIMPLIFIED VOLCANOLOGICAL MODEL}

A schematic volcanological model for the Rudnik Mts. volcanointrusive complex is given in Figure 8. The model summarizes in a most simplistic way all of the available information and proposes a possible succession of igneous processes from the early Oligocene to the Early Miocene.

The first igneous event occurred $>30$ Ma. when the extrusive and shallow intrusive dacites and andesites originated (Figure 8a). As evidence of explosive volcanic activity at this stage is lacking, the model assumes that the event was exclusively associated with extrusive to shallow intrusive activity. 
Volcanic processes recurred after a repose period of several million years, by the beginning of the Miocene ( $23 \mathrm{Ma})$. It is very likely that during this time, formation of lacustrine depositional systems also occurred (Figure 8b). This synthesis suggests that before the second magmatic event in the area of the present day Rudnik Mts. Orefield a large and presumably stratified magma chamber existed (Figure 8c). Due to advanced magmatic differentiation, the roof parts of this magmatic chamber were extremely depleted in crystals and enriched in magmatic gases, whereas its internal parts were progressively less gas- and more crystal-rich. The model involves a scenario according to which the chamber hanging wall did not collapse due to a simple overpressurisation of the underlying gas-rich magma, but in response to injections of water-saturated lamproite-like mafic melts from beneath (Figure 8d). This triggered huge explosive volcanic activity that probably had Plinian to sub-Plinian characteristics and produced large eruption columns and various pyroclastic fall and pyroclastic flow deposits (Figure 8e). This stage left behind numerous relicts of welded to non-welded ignimbrites and subordinate lapilli-fall deposits. After the gas-rich roof magma portions had emptied, crystal-rich and gas-poor melts reached eruption levels. This gave rise to formation of various coherent quartzlatite facies, from high-aspect ratio extrusions and lava domes to variously shaped subvolcanic intrusions (Figure 8f). The presence of granular textured monzogranite as well as strong contact metamorphic effects indicate that large masses of quartzlatite did not reach the surface, but remained to crystallize at shallow crustal levels. On crystallization of these magmatic masses, the igneous processes in the Rudnik Mts. area terminated.

The phase of formation of polymetallic mineralization followed the afore-mentioned magmatic events. The precipitation of mineralization was controlled by a large hydrothermal system that developed in the hanging wall of the solid but still hot magmatic intrusive body. As already argued above, this model proposes that incorporation of lamproite-like and water-rich mafic melts contributed greatly to the hydrothermal potential of the acid magma. Decompression of these fluids induced subsurface and superficial brecciation and deposition of ore minerals (Figure $8 \mathrm{~g}$ ).

\section{CONCLUSIONS}

This study demonstrates that there is still room for large improvements in our understanding of how igneous and metallogenic processes were linked during Cenozoic magmatism of the Balkan Peninsula. The main conclusions are as follows:

1. The Rudnik Mts. volcano-intrusive complex formed in two magmatic events.

2. The first magmatic event was associated with the formation of extrusive to shallow intrusive dacites; this phase occurred before $30 \mathrm{Ma}$.

3. The second event developed around 23 Ma. It was much more heterogeneous in terms of volcanic activity and magmatic products; this magmatism produced various products of quartzlatitic magma depending on the crystallization conditions.

4. One of the most prominent petrogenetic processes of the second event was mixing between a lamproite-like magma and dacitic melts; this process most likely triggered large explosive Plinian to sub-Plinian events.

5. According to the simplified volcanological model, magma mixing was crucial for mineralization processes in the Rudnik Mts. volcano-intrusive complex; injected lamproite-like and water-saturated melt provided conditions for a strong hydrothermal phase, formation of hydraulic breccia and precipitation of ore minerals.

\section{Acknowledgement}

The authors thank 'Rudnik and Flotation - Rudnik' for permitting publication of data which were part of a volcanological study done for the needs of the company. Discussions with Dejan PRELEVIĆ were extremely important in formulating some of the ideas in the manuscript. We thank Marina LAZAROV for help with zircon separation and LA-ICP-MS analyses. The study was partly financed by the project OI176016 funded by the Ministry of Education, Science and Technological Development of the Republic of Serbia and by Serbian Academy of Sciences and Arts. The editorial handling by V. BERMANEC and L. PALINKAS̆ as well as constructive reviews by S. BOROJEVIĆ ŠOŠTARIĆ and M. BELAK is appreciated.

\section{REFERENCES}

BALOGH, K. (1985): K/Ar dating of Neogene volcanic activity in Hungary: Experimental technique, experiences and methods of chronologic studies.- "ATOMKI“", Rep. D/1., 277-288.

BOROJEVIĆ ŠOŠTARIĆ, S., CVETKOVIĆ, V., NEUBAUER, F., PALINKAŠ, L.A., BERNROIDER, M. \& GENSER, J. (2012): Oligocene shoshonitic rocks of the Rogozna Mts. (Central Balkan Peninsula): evidence of petrogenetic links to the formation of Pb-Zn-Ag ore deposits.- Lithos, 148, 176-195.

BOROJEVIĆ ŠOŠTARIĆ, S., PALINKAS̆, L.A., NEUBAUER, F., HURAI, V., CVETKOVIĆ, V., ROLLER-LUTZ, Z., MANDIĆ, M. \& GENSER, J. (2013): Silver-base metal epithermal vein and listwanite hosted deposit Crnac, Rogozna Mts., Kosovo, part II: A link between magmatic rocks and epithermal mineralization.- Ore Geology Reviews, 50, 98-117.

BRKOVIĆ, T., RADOVANOVIĆ, Z. \& PAVLOVIĆ, Z. (1980): Osnovna geološka karta SFRJ 1:100000. Tumač za list Kragujevac L34-138 [Basic Geological Map of SFRY 1:100000, Geology of the Kragujevac sheet - in Serbian].- Savezni geološki zavod, Beograd, 60 p.

CAS, R.A.F. \& WRIGHT, J.V. (1987): Volcanic Successions.- Kluwer Academic Publishers, $544 \mathrm{p}$.

CIOBANU, C., COOK, N. \& STEIN, H. (2002): Regional setting and geochronology of the Late Cretaceous banatitic magmatic and metallogenetic belt.Mineralium Deposita 37, 541-567. doi: 10.1007/s00126-002-0272-9

CVETKOVIĆ, V., KNEŽEVIĆ, V. \& PECSKAY, Z. (2000a): Tertiary igneous formations of the Dinarides, Vardar zone and adjacent regions: from recognition to petrogenetic implications.- In: KARAMATA, S. \& JANKOVIC, S. (eds.): Geology and Metallogeny of the Dinarides and the Vardar zone. The Academy of Sciences and Arts of the Republic of Srpska, Collections and Monographs 1, Dpt. of Natur., Math. and Techn. Sci., 1, 245-253.

CVETKOVIC, V., PRELEVIĆ, D. \& PECSKAY, Z. (2000b): Lamprophyric rocks of the Miocene Borač Eruptive Complex (Central Serbia, Yugoslavia).Acta Geol. Hung., 43/1, 25-41.

CVETKOVIĆ, V. \& PÉCSKAY, Z. (1999): The Early Miocene eruptive complex of Borač (central Serbia): volcanic facies and evolution over time. Extended abstract. Carpathian Geology 2000, October 11-14, 1999, Smolenice.- Geologica Carpathica, 50, 91-93.

CVETKOVIĆ, V., POLI, G. \& PRELEVIĆ, D. (2001): Eruptive history and lowpressure evolution of the Early Miocene Borač eruptive complex (Central Serbia). In: DOWNES, H. \& VASELLI, O. (eds.): Tertiary magmatism in the Dinarides Balkan Peninsula.-Acta Volcanologica, 13/(1/2), 127-143.

CVETKOVIĆ, V., POLI, G., CHRISTOFIDES, G., KORONEOS, A., PECSKAY, Z., RESIMIĆ-ŠARIĆ, K. \& ERIĆ, V. (2007): The Miocene granitoid rocks of Mt. Bukulja (central Serbia): evidence for Pannonian extension-related granitoid magmatsim in the northern Dinarides.- Eur. J. Mineral., 19/4, 513-532. doi: 10.1127/0935-1221/2007/0019-1736

CVETKOVIĆ, V., PRELEVIĆ, D., DOWNES, H., JOVANOVIĆ, M., VASELLI, O. \& PECSKAY, Z. (2004): Origin and geodynamic significance of Tertiary 
post-collisional basaltic magmatism in Serbia (central Balkan Peninsula).Lithos, 73, 3-4, 161-186. doi: 10.1127/0935-1221/2007/0019-1736

CVETKOVIĆ, V., PRELEVIĆ, D. \& SCHMID, S. (2016): Geology of SouthEastern Europe.- In: PAPIĆ, P. (ed.): Mineral and Thermal Waters of Southeastern Europe. Springer, 1-30. doi: 10.1007/978-3-319-25379-4 1

CVETKOVIĆ, V., ŠARIĆ, K., PRELEVIĆ, D., GENSER, J., NEUBĀUER, F., HÖCK, V. \& VON QUADT, A. (2013): An anorogenic pulse in a typical orogenic setting: The geochemical and geochronological record in the East Serbian latest Cretaceous to Palaeocene alkaline rocks.- Lithos, 180-181, 181-199. doi: 10.1016/j.lithos.2013.08.013

CVETKOVIĆ, V., ŠARIĆ, K., PECSKAY, Z. \& GERDES, A. (2014): Had Late Oligocene-Early Miocene magmatism in the Dinarides different phases: The case study of the Rudnik Mts. volcanic complex. Proceedings of XX CBGA Congress, Tirana, Albania, 24-26 September 2014. Bul. Shk. Gjeol., 1/2014 - Special Issue $432 \mathrm{p}$.

FILIPOVIĆ, I., MARKOVIĆ, B., PAVLOVIĆ, Z., RODIN, V. \& MARKOVIĆ, O. (1978): Osnovna geološka karta SFRJ 1:100000. Tumač za list Gornji Milanovac L34-137 [Basic Geological Map of SFRY 1:100000, Geology of the Gornji Milanovac sheet - in Serbian].- Savezni geološki zavod, Beograd, $65 \mathrm{p}$.

FOLEY, S.F., VENTURELLI, G., GREEN, D.H. \& TOSCANI, L. (1987): The ultrapotassic rocks: characteristics, classification and constraints for petrogenetic models.- Earth Science Reviews, 24, 81-134. doi: 10.1016/ 0012-8252(87)90001-8

GERDES, A. \& ZEH, A. (2009): Zircon formation versus zircon alteration-new insights from combined U-Pb and Lu-Hf in situ LA-ICP-MS analyses, and consequences for the interpretation of Archean zircon from the Central Zone of the Limpopo Belt.- Chemical Geology, 261, 230-243.

JANKOVIĆ, S. (1997): The Carpatho-Balkanides and adjacent area: A sector of the Tethyan Eurasian metallogenic belt.- Mineralium Deposita, 32, 426-433.

JANKOVIĆ, S. (1966/67): Metalogenetske provincije i epohe u Jugoslaviji.Zbornik radova Rudarsko-geološkog fakulteta, Beograd, 9/10, 57-83.

JANKOVIĆ, S. (1984): Major metallogenic units and ore deposits in Yugoslavia.Exp. Memoir of the metallogenic map of Europe, 1:2500000, INESCO, Paris, 385-395.

JANKOVIĆ, S., JELENKOVIĆ, R. \& VUJIĆ, S. (2003): Mineral resources and potential prognosis of metallic and non-metallic mineral raw materials in Serbia and Montenegro at the end of the XX Century. Engineering Academy of Serbia and Montenegro, Section of Mining and Geology sciences, Special Issue 2, Beograd, p. 876, ISBN: 86-903409-3-X.

JOVANOVIĆ, M., DOWNES, H., VASELLI, O., CVETKOVIĆ, V., PRELEVIĆ, D. \& PECSKAY, Z. (2001): Paleogene mafic alkaline volcanic rocks of East Serbia.- In: DOWNES, H. \& VASELLI, O. (eds.): Tertiary magmatism in the Dinarides Balkan Peninsula.- Acta Volcanologica, 13, 1/2, 159-173.

KARSLI, O., CHEN, B., AYDIN, F. \& SEN, C. (2007): Geochemical and $\mathrm{Sr}-\mathrm{Nd}-\mathrm{Pb}$ isotopic compositions of the Eocene Dolek and Saricicek Plutons, Eastern Turkey: Implications for magma interaction in the genesis of high-K calc-alkaline granitoids in a post-collision extensional setting.- Lithos, 98, 67-96.

KORONEOS, A., POLI, G., CVETKOVIĆ, V., CHRISTOFIDES, G., KRSTIĆ, D. \& PECSKAY, Z. (2011): Petrogenesis and tectonic inferences from the study of the Mt. Cer pluton (West Serbia).- Geol. Mag., 148, 1, 89-111.

LE BAS, M.J., LEMAITRE, R.W., STRECKEISEN, A. \& ZANETTIN, B. (1986): A chemical classification of volcanic rocks based on the total alkalisilica diagram.- Journal of Petrology, 27, 745-750.

LOFGREN, G. (1971): Experimentally produced devitrification textures in natural rhyolitic glass.- Geological Society of America Bulletin, 82, 111-123. doi: 10.1130/0016-7606(1971)82\%5B111:EPDTIN\%5D2.0.CO;2

MATENCO, L. \& RADIVOJEVIĆ, D. (2012): On the formation and evolution of the Pannonian Basin: Constraints derived from the structure of the junction area between the Carpathians and Dinarides.- Tectonics, 31, 6, TC6007, doi: $10.1029 / 2012 \mathrm{TC} 003206$

MAROVIĆ, M., KRSTIĆ, N., STANIĆ, S., CVETKOVIĆ, V. \& PETROVIĆ, M. (1999): The evolution of Neogene sedimentation provinces of central Balkan Peninsula.- Bulletin of Geinstitute, 36, 25-94.

McDONOUGH, W.F. \& SUN, S.S. (1995): The composition of the Earth.-Chemical Geology, 120/ (3-4), 223-253. doi: 10.1016/0009-2541(94)00140-4

MILIĆ, Č.R. (1972): Rudonosne strukture i faktori kontrole orudnjavanja prostora u polimetaličnom ležištu Rundik.- Zbornik radova VII kongresa geologa SFRJ, Zagreb, III, 111-124.

MLADENOVIĆ, A., TRIVIĆ, B. \& CVETKOVIĆ, V. (2015): How tectonics controlled post-collisional magmatism within the Dinarides: Inferences based on study of tectono-magmatic events in the Kopaonik Mts. (Southern Serbia).- Tectonophysics, 646, 36-49, doi: 10.1016/j.tecto.2015.02.001

NELSON, S.T. \& MONTANA, A. (1992): Sieve-textured plagioclase in volcanic rocks produced by rapid decompression.- Am. Mineral., 77, 1242-1249.

PECCERILLO, A. \& TAYLOR, S.R. (1976): Geochemistry of Eocene calcalkaline volcanic rocks from Kastamonu area, northern Turkey.-Contributions to Mineralogy and Petrology, 58, 63-81.

PHILLIPS, W.J. (1972): Hydraulic fracturing and mineralisation.- Journal of the Geological Society of London, 128, 337-359.
POPOVIĆ, R. \& UMELJIĆ, G. (2015): Metalogenija planine Rudnik (pozicija u vremenu i prostoru). Povremena izdanja Rudnik i flotacija 'Rudnik' doo Rudnik, Beograd, 224 p., ISBN: 978-86-918511-0-1.

PRELEVIĆ, D., CVETKOVIĆ, V. \& FOLEY, S.F. (2001a): Composite igneous intrusions from Serbia: two case studies of interaction between lamprophyric and granitoid magmas.- In: DOWNES, H. \& VASELLI, O. (eds.): Tertiary magmatism in the Dinarides Balkan Peninsula.-Acta Vulcan., 13, 145-157.

PRELEVIĆ, D., FOLEY, S., CVETKOVIĆ, V., JOVANOVIĆ, M. \& MELZER, S. (2001b): Tertiary ultrapotassic rocks from Serbia, Yugoslavia.- In: DOWNES, H. \& VASELLI, O. (eds.): Tertiary magmatism in the Dinarides Balkan Peninsula.- Acta Vulcan., 13, 116-135. doi: 10.1130/2007.2418(06)

PRELEVIĆ, D., CVETKOVIĆ, V. \& JOVANOVIĆ, M. (2000): The composite dome of Beli Kamen (Mt. Rudnik, Central Serbia) - the example of a specific interaction of lamprophiric and granitoid magma.- In: KARAMATA, S. \& JANKOVIĆ, S. (eds.): Geology and Metallogeny of the Dinarides and the Vardar zone. The Academy of Sciences and Arts of the Republic of Srpska, Collections and Monographs 1, Dpt. of Natur., Math. and Techn. Sci. 1, $255-267$.

PRELEVIĆ, D., FOLEY, S.F., CVETKOVIĆ, V. \& ROMER, R.L. (2004): Origin of minette by mixing of lamproite and dacite magmas in Veliki Majdan, Serbia.- J. Petrol., 45/4, 759-792. doi: 10.1093/petrology/egg109

PRELEVIĆ, D., FOLEY, S.F., ROMER, R.L., CVETKOVIĆ, V. \& DOWNES, H. (2005): Tertiary Ultrapotassic Volcanism in Serbia: Constraints on Petrogenesis and Mantle Source Characteristics.- Journal of Petrology, 46/7, 14431487. doi: 10.1093/petrology/egi022

PRELEVIĆ, D., FOLEY, S.F. \& CVETKOVIĆ, V. (2007): A review of petrogenesis of Mediterranean Tertiary lamproites: A perspective from the Serbian ultrapotassic province.- Geological Society of America, Special Paper, 418, 113-129. doi: 10.1130/2007.2418(06)

RADULOVIĆ, A. \& ERIĆ, V. (1997): Karta magmatizma rudnog polja Rudnik Izveštaj.- Geoinsitut, Beograd, $19 \mathrm{p}$.

ROBERTSON, A.H.F., KARAMATA, S. \& ŠARIĆ, K. (2009): Overview of ophiolites and related units in the Late Palaeozoic-Early Cenozoic magmatic and tectonic development of Tethys in the northern part of the Balkan region.Lithos, 108, 1-4, 1-36.

SCHEFER S., CVETKOVIĆ, V., FUGENSCHUH, B., KOUNOV, A., OVTCHAROVA, M., SCHALTEGGER, U. \& SCHMID, M.S. (2011): Cenozoic granitoids in the Dinarides of southern Serbia: age of intrusion, isotope geochemistry, exhumation history and significance for the geodynamic evolution of the Balkan Peninsula.- Int. J. Earth Sci. (Geol. Rundsch.), 100, 5, 1181-1206. doi: 10.1007/s00531-010-0599-x

SCHMID, S.M., BERNOULLI, D., FUGENSCHUH, B., MATENCO, L., SCHEFER, S., SCHUSTER, R., TISCHLER, M. \& USTASZEWSKI, K. (2008): The Alpine-Carpathian-Dinaridic orogenic system: correlation and evolution of tectonic units.- Swiss J. Geosci., 101, 139-183.

STEIGER, R.H. \& JÄGER, E. (1977): Subcommission on geochronology: Convention on the use of decay constants in geo- and cosmochronology.- Earth Planet. Sci. Lett., 36, 359-362. doi: 10.1016/0012-821X(77)90060-7

STOJANOVIĆ, J.N., RADOSAVLJEVIĆ, S.A., KARANOVIĆ, LJ.C \& CVETKOVIĆ, LJ. (2006): Mineralogy of W-Pb-Bi ores from Rudnik Mt., Serbia.- Neues Jahrbuch für Mineralogie - Abhandlungen, 182, 299-306. doi: $10.1127 / 0077-7757 / 2006 / 0053$

TERZIĆ, M. \& SVEŠNJIKOVA, E.V. (1991): Age of leucite-bearing rocks in Yugoslavia.- Comptes Rendus des Seances de la Societe de Serbe de Geol. (1987, 1988 et 1989), 283-287.

TERZIĆ, M. \& TERZIĆ, S. (1972): Ignimbriti šire oblasti planine Rudnika.- VII Kongres geologa Jugoslavije, Zagreb, 2, 359-369.

TERZIĆ, M. \& VUKOV, M. (1984): Prilog petrologiji Šumadije - Daciti Slavkovice.- Zapisnici Srpskog gološkog društva za 1983, 17-23.

TOŠOVIĆ, R. (1997): Morfogenetski tipovi orudnjenja i paragenetske asocijacije u polimetaličnom ležištu Rudnik.- Magistarska teza, Rudarsko-geološki fakultet, $109 \mathrm{p}$.

TOŠOVIĆ, R. (2000): Genetsko i geološko-ekonomsko modeliranje polimetaličnog ležišta Rudnik.- Doktorska disertacija, Rudarsko-geološki fakultet, $259 \mathrm{p}$.

VON QUADT, A., IVANOV, Z. \& PEYTCHEVA, I. (2001): The Central Srednogorie (Bulgaria) part of the $\mathrm{Cu}$ (Au-Mo) belt of Europe: A review of the geochronological data and the geodynamical models in the light of the new structural and isotopic studies. - In: PIESTRZYNSKI, A. (ed.): Mineral Deposits at the Beginning of the $21^{\text {st }}$ Century. Proceedings of the Joint Sixth Biennial SGA-SEG Meeting, Krakow. Tokyo: A.A. Balkema Publishers, 555-558.

VON QUADT, A., MORITZ, R., PEYTCHEVA, I. \& HEINRICH, C. (2005): Geochronology and geodynamics of Late Cretaceous magmatism and $\mathrm{Cu}-\mathrm{Au}$ mineralization in the Panagyurishte region of the Apuseni-Banat-TimokSrednogorie belt, Bulgaria.- Ore Geology Reviews 27, 95-126. doi: 10.1016/j.oregeorev.2005.07.024 
